\title{
Association analysis for yield and related traits in fenugreek (Trigonella foenum-graecum L.) under different environmental conditions
}

\author{
Preeti Yadav*, Sumit Deswal and Avtar Singh \\ Department of Vegetable Science, CCS Haryana Agricultural University Hisar-125004 (Haryana), INDIA \\ *Corresponding author. E-mail: preetiyadav436@gmail.com \\ Received: September 25, 2016; Revised received: February 22, 2017; Accepted: May 20, 2017
}

\begin{abstract}
Sixteen diverse genotypes of fenugreek (Trigonella foenum-graecum L.) were grown in five (E1 to E5) environments which were created by different date of sowing during the rabi seasons at the Vegetable Farm of CCS HAU, Hisar. (29 $\left.15^{\prime} \mathrm{N}, 75^{\circ} 69^{\prime} \mathrm{E}\right)$ during 2012-13. Observations were recorded on ten randomly selected plants from each genotypes in each replications for characters viz. field emergence index, days to $50 \%$ flowering, plant height, number of pods per plant, number of branches per plant, number of seeds per pod, pod length, seed yield ( $q / h a)$, test weight, seed germination, seed vigour index-I and II. The estimation of genotypic and phenotypic coefficients (GCV and PCV) variation in all the environments was consistently decreasing with the delaying in sowing date for all the character studied except plant height and test weight indicating that the environmental influence was comparatively more pronounced for these characters in expressing the phenotypic performance of different genotypes. Highest GCV and PCV was estimated as $50.36 \%$ and $55.93 \%$, respectively for seed vigour index-I in E1. High value of heritability estimated for characters seed yield, seed vigour index-II, seed germination and branches per plant (above $70 \%$ ) in E1 revealed that these were less influenced by environment and low heritability estimated for days to $50 \%$ flowering in E2, plant height in E2, seeds per pod in E3, field emergence index in E5 indicated high influence of environment. Based on environmental indices, the environment E2 was most favourable for all the characters studied except field emergence index.
\end{abstract}

Keywords: Environmental Indices, Fenugreek, GCV, Genetic advance, Heritability, PCV

\section{INTRODUCTION}

Fenugreek (Trigonella foenum graecum L.) is locally known as Methi or Metha and a member of family Leguminosae (fabaceae), is an important multiuse seed crop of arid and semi arid subtropical regions .It is native to the countries bordering the eastern shores of Mediterranean region, extended to Central Asia. It is a self pollinated crop with chromosome no. $2 \mathrm{n}=16$ (Flayer, 1930) and an annual herb with trifoliate leaves blooms into white flowers tinged with violet margins. The flowers develop into thin long brown pods containing 15- 20 seeds. In part of Asia, the young plants are used as potherbs and the seeds as a spice or as herbal medicine (Lust 1986, Petropoulos 2002). Fenugreek, perhaps, is best known for the presence of the distinctive, pungent aromatic compounds in seed (Max, 1992) that impart flavor, color and aroma to foods, making it a highly desirable supplement for use in culinary applications.

The genetic improvement of any crop depends upon the existence of genetic variability, its nature and magnitude as it helps in formulating selection criteria for different traits in a breeding programme. So, the primary consideration is to bring about the genetic improvement in the available germplasm, the estimates of which are frequently subjected to environmental changes (Goswami, 2011). Hence, keeping in view, the present study was attempted to find out the magnitude of variability, heritability and genetic advance for different characters in fenugreek under five different environmental conditions.

\section{MATERIALS AND METHODS}

The experimental material comprised of 16 genotypes of fenugreek viz. FGK-30, Hisar Sonali, Hisar, Suverna, HM-219, HM-355, HM-273, HM-273-1, HM-291, HM-293-1, Hisar Mukta, HM-348, HM-257, Hisar Manohar, Pusa Early Bunching, Prabha, and Rmt361.These germplasm were evaluated in randomized block design and plot size was $2.4 \times 3.0 \mathrm{~m}$ and $8(3 \mathrm{~m}$ long each) rows per plot. Environments studied were created by different date of sowing i.e., $16^{\text {th }}$ October, $1^{\text {st }}$ and $16^{\text {th }}$ November, $2^{\text {nd }}$ and $17^{\text {th }}$ December 2012 , to judge the variability within the characters.

All recommended agronomic practices and plant protection measures were followed timely for successful rising of crop. Randomly ten competitive plants were taken to record the observations for different characters namely field emergence index, days to $50 \%$ flowering, plant height $(\mathrm{cm})$, pods per plant, number of branches per plant, pod length $(\mathrm{cm})$, number of seeds 
Table 1. List of environments.

\begin{tabular}{lc}
\hline Environments & Date of owing \\
\hline E1 & $16^{\text {th }}$ October, 2012 \\
E2 & $1^{\text {st }}$ November, 2012 \\
E3 & $16^{\text {th }}$ November, 2012 \\
E4 & $2^{\text {nd }}$ December, 2012 \\
E5 & $17^{\text {th }}$ December, 2012 \\
\hline
\end{tabular}

per pod, seed yield ( $\mathrm{q} / \mathrm{ha})$, test weight, seed germination (\%), seed vigour index-I and seed vigour index-II. Seed yield was recorded on the plot basis and further calculated in $\mathrm{q} / \mathrm{ha}$. One thousand seeds were counted in each replication of every genotype and weighed for calculating test weight (g). Rolled towel method (BP) was used for seed germination test. Four hundred seeds in four replications of each genotype were taken to record the seed germination. First count of normal seedling was taken on $5^{\text {th }}$ day and final count on $14^{\text {th }}$ day.

Seedling vigour indices: seedling vigour indices were calculated by following Baki and Anderson (1973) method:

Vigour index-I = Standard germination (\%) X Average seedling length $(\mathrm{cm})$

Vigour index-II = Standard germination (\%) X Average seedling dry weight $(\mathrm{g})$

These quantitative characters were used to estimate phenotypic and genotypic coefficient of variation, broad sense heritability, genetic advance and genetic advance as percent of mean.

The data on each character were subjected to standard statistical analysis of variance for each environment separately (Panse and Sukhatme, 1978). The phenotypic and genotypic coefficient of variation (PCV, GCV) and expected genetic advance (GA) were calculated following Johnson et al. (1955). Heritability in broad sense was calculated in accordance with Allard (1960). Environmental index was calculated by following Finlay and Wilkinson (1963).

\section{RESULTS AND DISCUSSION}

Analysis of variance for each character was done in each environment to know the differences in thegenotypes. Significant difference between genotypes were observed for all the characters namely, days to $50 \%$ flowering, plant height $(\mathrm{cm})$, pods per plant, number of branches per plant, pod length $(\mathrm{cm})$, number of seeds per pod, seed yield ( $\mathrm{q} / \mathrm{ha}$ ), test weight, seed germination (\%), seed vigour index-I and seed vigour indexIIin all environments except seed germination in E3. It indicates that the genotypic differences are actual and expressed in all the environments.

Performance of fenugreek genotypes under different environments: Effect of different environments on various characters of fenugreek genotypes were studied in Table 2. Estimated mean for branches per plant (10.1), pods per plant (86.3), pod length (9.5), seeds

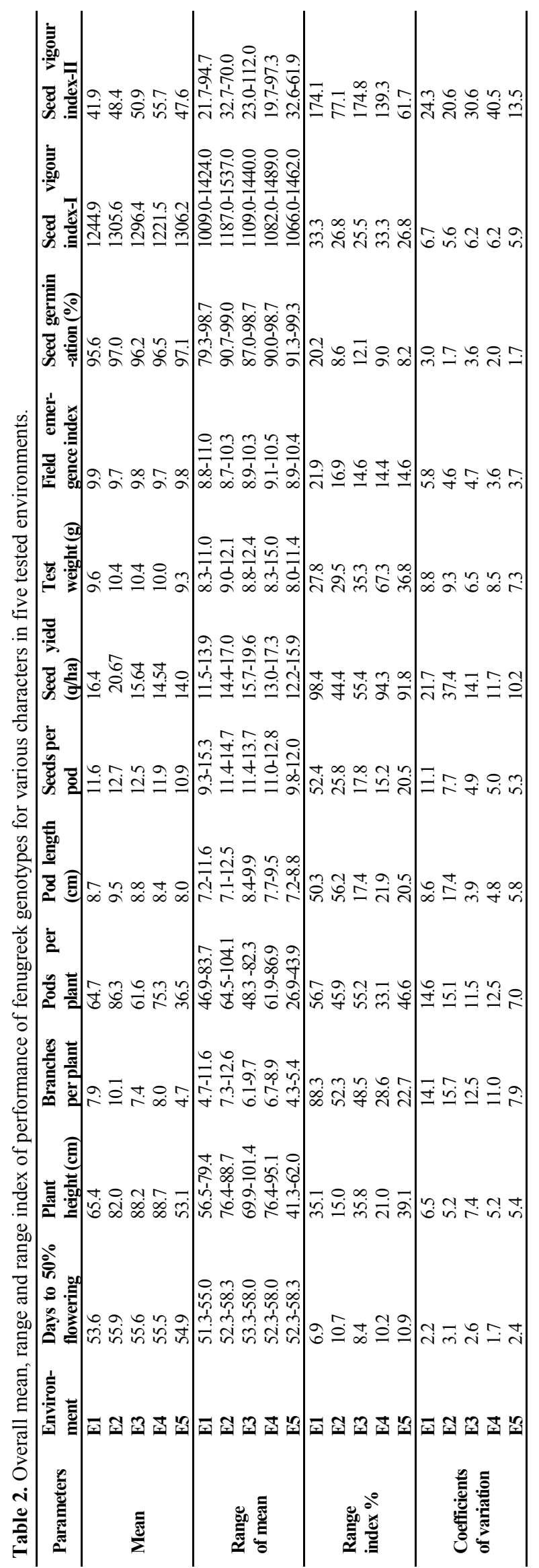


Preeti Yadav et al. / J. Appl. \& Nat. Sci. 9 (2): 1176 - 1181 (2017)

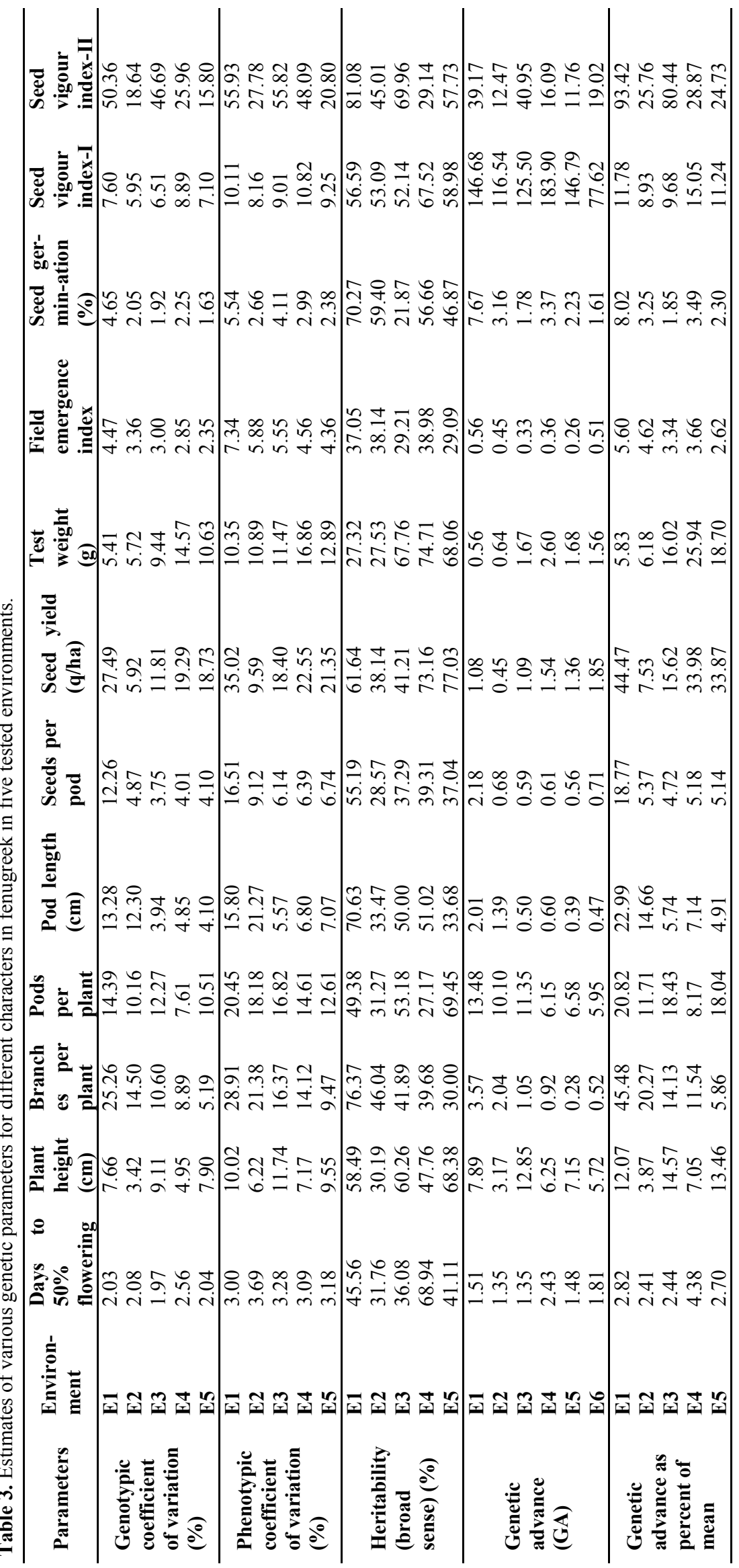


Table 4. Environmental indexes $(I j)$ estimated as deviation from the grand mean of genotypes for various characters in different environments.

\begin{tabular}{lcccccc}
\hline \multirow{2}{*}{ Characters } & \multicolumn{4}{c}{ Environmental indexes $(\boldsymbol{I} \boldsymbol{j})$ in test environments } & \multirow{2}{*}{ Grand Mean } \\
\cline { 2 - 5 } & $\mathbf{E 1}$ & $\mathbf{E 2}$ & $\mathbf{E 3}$ & $\mathbf{E 4}$ & $\mathbf{E 5}$ & 55.17 \\
Days to 50\% flowering & -1.59 & +0.74 & +0.41 & +0.28 & -0.26 & 74.24 \\
Plant height (cm) & -8.85 & +7.71 & +13.94 & +14.44 & -21.14 & 7.43 \\
Branches per plant & +0.43 & +2.64 & +0.06 & +0.52 & -2.71 & 63.04 \\
Pods per plant & +1.70 & +23.21 & -1.43 & +12.23 & -26.4 & 8.47 \\
Pod length (cm) & +0.27 & +0.75 & +0.32 & -0.06 & -0.51 & 11.81 \\
Seeds per pod & -0.22 & +0.84 & +0.69 & +0.07 & -0.90 & 0.35 \\
Seed yield (kg/plot) & -0.18 & +0.06 & +0.14 & -0.03 & -0.07 & 4.80 \\
Seed yield (q/ha) & -2.36 & +1.13 & +2.18 & -0.27 & -0.77 & 9.85 \\
Test weight (g) & -0.24 & +0.55 & +0.59 & +0.16 & -0.54 & 9.82 \\
Field emergence index & +0.08 & -0.15 & -0.01 & -0.09 & -0.01 & 96.61 \\
Seed germination (\%) & -0.99 & +0.40 & -0.46 & -0.14 & +0.45 & 1277.11 \\
Seed vigour index-I & -32.22 & +28.53 & +19.3 & -55.58 & +29.11 & 49.05 \\
Seed vigour index-II & -7.12 & -0.62 & +1.85 & +6.69 & -1.5 & \\
\hline
\end{tabular}

per pod (12.7) and test weight (10.4) was found to be maximum in E2. Maximum plant height (88.7) and seed vigour index-II (55.7) was estimated in E4. Days to $50 \%$ flowering (53.6), field emergence index (9.9), seed germination (97.1), seed vigour index-I (1306.2) and seed yield (20.67) was found maximum in E1, E1, E5, E5, E2 respectively. Crop sown on E2produced significantly taller plants, higher number of branches, pods per plant, pod length, seeds per pod, seed yield, test weight and other related components in comparison to other dates of sowing due to prolonged vegetative growth period because of congenial environmental conditions especially atmospheric temperature in E2 which formed a basis for rapid cell division in the meristematic tissues of the crop and led to better growth attributes under E2. The E5 experienced sub-optimal temperature regime which retarded their growth compared to crop grown on earlier dates. Halesh et al. (2000) also find the similar results with respect to plant height and branches per plant. Characters like days to $50 \%$ flowering, pod length, seeds per pod, seed germination and field emergence index were found to be consistent in its behavior, both at phenotypic and genotypic level having lowest coefficient of variation. It suggested that these traits were least influenced by the non genetic factors and hence these were quite stable.

Genetic parameters of fenugreek genotypes under different environments: Effect of different environments on various genetic parameters of fenugreek genotypes were studied in Table 3 . All the characters studied had wide variability which indicated that there is presence of sufficient amount of genetic variability of these traits and can be exploited by breeding procedure for the improvement of these characters. The range of PCV for different traits was observed from $3.00 \%$ (days to $50 \%$ flowering) to $55.93 \%$ (Seed vigour index-II) in E1, in E2 observed PCV ranged from 3.69 $\%$ (days to $50 \%$ flowering) to $27.78 \%$ (Seed vigour index-II); in E3 it ranged from $3.28 \%$ (days to $50 \%$ flowering) to $55.82 \%$ (Seed vigour index-II); in E4
PCV range was $3.09 \%$ (days to $50 \%$ flowering) to $48.09 \%$ (Seed vigour index-II) and in E5 it was 3.18 $\%$ (days to $50 \%$ flowering) to $21.35 \%$ (Seed Yield). Whereas in case of range of GCV, it was estimated $2.03 \%$ (days to $50 \%$ flowering) to $50.36 \%$ (Seed vigour index-II) in E1, in E2 it was ranged from 2.08 $\%$ (days to $50 \%$ flowering) to $18.64 \%$ (Seed vigour index-II); range of GCV in E3 (days to $50 \%$ flowering) was $1.97 \%$ to $46.69 \%$ (Seed vigour index-II); in E4 it was $2.56 \%$ (days to $50 \%$ flowering) to $25.96 \%$ (Seed vigour index-II) and it ranged from $2.04 \%$ (days to $50 \%$ flowering) to $18.73 \%$ (Seed Yield) in E5. The presence of wide range of $\mathrm{PCV}$ and GCV revealed that there is large extent of phenotypic and genetic variability. The PCV estimated was, in general higher than that of GCV for all the traits indicating the effect of date of sowing and also the environmental effect on the phenotypic expression of the traits. This implied that the nongenetic causes affect the value of genetic correlation because of the environmental factors. It is also conformity with the earlier findings of Prajapati et al. (2010) and Verma et al. (2012) in fenugreek for many of these traits.

The broad sense heritability estimated were classified into three groups i.e., value for heritability estimates having more than 70 for high heritability, 50 to 70 for medium heritability and less than 50 for low heritability. Broad sense heritability estimated was high for branches per plant, pod length, seed germination \%, seed vigour index-II in E1; seed yield and test weight in E3; seed yield in E5. While moderate heritability was estimated for plant height, seeds per pod, seed yield, seed vigour index-I in E1; seed germination and seed vigour index-I in E2; plant height, pods per plant, pod length, test weight, seed viogur index-I \& II in E3; days to $50 \%$ flowering, pod length, seed germination and seed viogur index-I in E4; plant height, test weight, seed vigour index-I \& II in E5. And remaining characters showed low heritability. Presence of high heritability indicated the preponderance of additive gene action in the expression of all these traits. Similar results have 
also obtained by Chandra et al. (2000) in fenugreek, Rao et al. (2006) and Biradar et al. (2007) in mungbean substantiating the results obtained in this study. The magnitude of genetic advance as per cent of mean ranged from $0.56 \%$ (test weight) to $146.68 \%$ (seed vigour index-I) in E1; $0.45 \%$ (field emergence index) to $116.54 \%$ (seed vigour index-I) in E2; $0.33 \%$ (field emergence index) to $125.50 \%$ (seed vigour index-I) in E3; $0.36 \%$ (field emergence index) to $183.90 \%$ (seed vigour index-I) in E4; $0.26 \%$ (field emergence index) to $146.79 \%$ (seed vigour index-I) in E5. The expected genetic advance would be low when the heritability is mainly due to non additive gene effect, but the genetic advance would be high when the heritability is due to additive gene effect (Panse, 1957). High heritability and high genetic advance are crucial for the improvement of any character. High estimates of genetic advance as percent of mean was observed for the characters, plant height in E3, branches per pod in E1, seed yield in E1, seed vigour index-II in E1 and E3, whereas lower values were estimated in days to $50 \%$ flowering and field emergence index in almost all environments. The traits exhibiting high heritability coupled with high genetic advance can be improved by direct selection. Low heritability coupled with low genetic advance and low GCV suggested presence of non-additive gene action and high GXE interaction. Verma et al. (2012) reported higher genetic advance for number of pods per plant, number of seeds, test weight and seed yield in fenugreek.

Grading of environments: The environment can be graded based upon the overall mean performance of the genotype studied (Finlay and Wilkinson 1963). Thus, an environmental index (which is the difference between the mean of characters at the environment created in question and the grand mean) has been calculated for all the characters and all the environments. It is observed that suitable environment in the present case, was different for different characters (Table 3 ). For branches per plant, pods per plant, pod length, Seeds per pod, seed germination and seed vigour index I E2 was most favourable; for days to $50 \%$ flowering $\mathrm{E} 1$, for plant height E4 and for test weight E3were found to be favourable one. These indexes were utilized to estimate the linearity and the deviation from the linearity component of response of individual genotypes representing their performance with respect to different quantitative characters over the test environments. So, the best environment tested was E2 followed by E1 and E3. Similar views were also reported by Kole and Shah (2013) with respect to different environmental conditions.

\section{Conclusion}

On the basis of above findings, it can be concluded that estimates of various genetic parameter were more or less same in E1 and E2 for many characters viz., seed germination, seed vigour index-I and II, branches per plant and seeds per pod. This indicated that E1 and E2 exerted almost similar environmental effects on the genetic expression of the characters, which was supported by almost similar environmental indexes of E1 and E2 for different characters. The significant impact on growth and yield attributes was found maximum in E2 and should be considered for yield improvement programme in fenugreek.

\section{REFERENCES}

Abdul-Baki, A. A. and Anderson, J. D. (1973). Vigour determination in soybean seed by multiple criteria. Crop Science, 13: 630-633

Allard, R. W. (1960). Principles of plant breeding. John Wiley and Sons. Inc., London and New York. Pp. 485

Biradar, K. S., Sailmath, P. M. and Ravikumar, R. L. (2007). Genetic variability for seedling vigour, yield and yield components in local germplasm collections of greengram (Vigna radiata (L.) Wilczek). Karnataka Journal of Agriculture Science, 20: 608-609

Chandra, K. S., Divakara, E.V. and Singh, D. (2000). Genetic variation and charcter association of seed yield and its components characters in fenugreek. Agri.Sci.Digest, 20: (2): 93-95

Flayer, J. K. (1930). Chromosome atlas of flowering plant. Georg Allen and Urwin London, Pp. 519

Finlay, K. W. and Wilkinson, G. N. (1963). The analysis of adaptation in plant breeding programme. Australian Journal of Agricultural Research, 14: 742-751

Goswami, T. (2011). Assessment of genetic variability in fenugreek. M.Sc. (Ag.) Horticulture Thesis, Institute of Agriculture, Visva-Bharati University, India.

Halesh, D. P., Gowda, M. C., Farooqi, A. A., Vasundhara, M. and Srinivasappa, K. N. (2000). Effects of dates of sowing and spacing on growth and yield in fenugreek (Trigonella foenum - graecumL.). Spices and aromatic plants: Challenges and opportunities in the new century.Contributory papers. Centennial conference on spices andaromatic plants, Calicut, Kerala, India; 20-23: 129-32

Johnson, H. W., Robinson, H. F. and Comstock, R. E. (1955). Genotypic and phenotypic correlations in soybean and their implications in selection. Agronomy $J$, $47: 477-483$

Lust, J. B. (1986). The Herb Book, Bantam Books Inc, New York.

Kole, P. C. and Saha, A. (2013). Correlation co-efficients of component characters with seed yield and their direct effects in path analysis in fenugreek grown under six environments. Journal of Horticulture and Forestry, 5:17-20

Max, B. (1992). This and that- essential pharmacology of herb and spices. Trends in Pharmacological Sci., 13:1520

Panse V. G. (1957). Genetics of quanitative characters in relation to plant breeding. Indian J. Genet., 17: 318-28

Panse, V. G. and Sukhatme, P. V. (1978) Statistical methods for agricultural workers. I.C.A.R., New Delhi.

Petropoulos, G. A. (2002). Fenugreek, The genus Trigonella. Taylor and Francis, London and New York Pp. 225

Prajapati, D. B.,Y. Ravindrababu and Prajapati, B. H. (2010) 
Preeti Yadav et al. / J. Appl. \& Nat. Sci. 9 (2): 1176 - 1181 (2017)

Genetic variability and character association in fenugreek (Trigonella foenum graecum L.) Journal of Spices and Aromatic Crops, 19 (1\&2): 61-64

Rao, G. R., Rao, Y. K. and Rao, C. M. (2006). Genetic divergence in mungbean. Indian Journal of Pulses Research,
19: 61-63

Verma, Preeti and Ali, Mashiat (2012). Genetic variability in fenugreek ((Trigonella foenum graecum L.) assessed in South Eastern Raj. International Journal of Seed spices, 2 (1): $56-58$ 